\title{
Proceeding
}

8th INSHS International Christmas Sport Scientific Conference, 5-7 December 2013. International Network of Sport and Health

Science. Szombathely, Hungary

\section{Attitudes of pupils at the primary schools towards motion games carried out at physical education classes}

\author{
ŠTEFAN ADAMČÁ, PAVOL BARTíK $\square$, MIROSLAV NEMEC \\ ${ }^{1}$ Department of Physical Education and Sports, Faculty of Humanities, MBU Banská Bystrica, Slovakia
}

\begin{abstract}
Adamčá, S., Bartík, P. \& Nemec, M. (2014). Attitudes of pupils at the primary schools towards motion games carried out at physical education classes. nincs a programban. J. Hum. Sport Exerc., 9(Proc1), pp.S223-S231. The research study is focused on the analysis of attitudes of pupils at the 2nd stage of primary schools towards teaching motion games at physical education classes considering the intersexual differences. The study sample consisted of 821 respondents, comprising pupils of the 5th to 9th grades from randomly selected primary schools. The main research method used in the research was based on the analysis of a questionnaire. Answers to particular questions provided by the respondents were analyzed quantitatively and qualitatively regarding the intersexual differences and complemented by the calculation of the statistical significance (by means of chi-square). The research was carried out during the school year 2011/2012. According to its results, motor and sports games are still popular with both boys and girls $-68.47 \%$ and $75 \%$ respectively - who consider motion and sports games their most favourite activities at physical education classes. The difference between boys and girls was statistically significant at the $p<0.05$ level. $36.94 \%$ of girls and $33.71 \%$ of boys stated that they play motion games at physical education classes once a week. According to both boys and girls, motion games are usually played in the main part of the class, as stated by $68.47 \%$ of girls and $61.36 \%$ of boys. Up to $87.39 \%$ of girls and $88.64 \%$ of boys hold the opinion that motion games shall be implemented into the course of classes to a greater extent. It was confirmed by the research that motion games have a significant socializing effect. Pupils believe that when playing motion games they make contact with their classmates in a faster way. $63.64 \%$ of boys and $54.95 \%$ of girls are convinced about this fact. During the research it was ascertained that motion games still represent the key factor in motivating pupils of primary schools to perform physical activities on regular basis as well as increase the popularity of sports and physical education classes. Key words: ATTITUDES OF PUPILS, MOTION GAMES, SPORTS AND PHYSICAL EDUCATION.
\end{abstract}

Corresponding author. Department of Physical Education and Sports, Faculty of Humanities, MBU Banská Bystrica,Slovakia. E-mail: Pavol.Bartik@umb.sk.

8th INSHS International Christmas Sport Scientific Conference, 5-7 December 2013. International Network of Sport and Health Science. Szombathely, Hungary.

JOURNAL OF HUMAN SPORT \& EXERCISE ISSN 1988-5202

(c) Faculty of Education. University of Alicante

doi:10.14198/jhse.2014.9.Proc1.02

VOLUME 9 | Proc1 | 2014 | S223 


\section{INTRODUCTION}

Physical activities and games have always been natural for every human being and society. They are present in all areas of life. For that reason it is natural that they are also a part of educational process (Argaj, 1999).

In recent years there has been a radical change in the attitude of Slovak society towards education, and lifelong learning. The need for innovation and adaptation to new requirements in the field of education has been the main reason for the transformation of educational process in Slovakia. Considering the subject area of health and physical activities the state curriculum is based on the fact that health represents a balance among physical, mental and social well-being (Novotna \& Adamcak, 2002).

Since teachers have the possibility to create new syllabuses, they can integrate also less-traditional physical activities into the course of sports and physical education classes. Naturally, this depends primarily on their skills, readiness and willingness to integrate less-known and alternative methods into the teaching process (Baranek \& Hrnciar, 2009).

Findings from the last couple of years are shocking since it appears that children and youth prefer a passive lifestyle. Their level of fitness and posture decreases, the number of children with health problems as well as obese children increases, while their physical performance and strength have been on the downgrade. There are more and more young people addicted to drugs and alcohol and smoking, which leads to rising number of cardio-vascular diseases and other health disorders of children and the youth (Michal, 2010). Therefore, this subject area focuses on directing and leading pupils to conscious need to care for their health by acquiring theoretical knowledge as well as practical experience of the health education.

The most significant change in teaching sports and physical education has been the effort to change the focus and objective of sports and physical education classes. This should lead to the openness and variety of the content as well as adjusting the content of the classes to school's conditions and interests of its pupils. The project in question is characterised by a higher level of freedom and responsibility of sports and physical education teachers to design programmes for different groups of pupils.

The predominance of sports games derives from the fact that the state curriculum enables to integrate new sports games in the course of education so that pupils can face new rules and adopt new skills. These games include floor-ball, frisbee, ringo, speedminton, etc (Adamcak, 2009).

All forms and modifications of physical games provide them with entertainment, emotional pleasure and distraction from everyday problems. They support the sense of teamwork and friendship and have a great communication and socialisation effect. An appropriate course of adequately chosen physical game motivates pupils to do more intensive physical activities and encourages even those who have not been interested in sports to go in for them (Argaj, 2011).

In our research, we were mainly focused on playful activities in the form of physical games which should be used at all stages of sports and physical education at school and included in various forms in all syllabus topics. The contribution of physical games to educational process is evident. They enrich children's lives with new activities, pupils adopt new skills and knowledge and last but not least, they make new or reinforce the existing contacts with other pupils as well as with teachers. 
The aim of our research was to identify and analyse the attitudes of pupils at the 2 nd stage of primary schools in Brezno towards implementing physical games in the course of sports and physical education classes.

\section{MATERIAL AND METHODS}

The study sample consisted of randomly selected pupils at the 2nd stage of primary schools in Brezno. The main research method was based on the analysis of the questionnaire. It was distributed during the second term of the school year 2011/2012. The pupils were given detailed information on how to fill in the questionnaire. The study sample consisted of 821 respondents $(54.32 \%$ of the boys and $45.68 \%$ of the girls) attending the 5 th to 9 th grade (Table 1 ).

The questionnaire method was used to determine the attitudes of pupils towards physical games and it was carried out at sports and physical education classes. The questionnaire was distributed at the beginning of the second term of the school year 2011/2012 and it was created and processed by the TAP programme provided by the company Gamo, Banská Bystrica.

In order to ascertain the differences in the pupils' answers more accurately, respective questions were analysed quantitatively and qualitatively regarding the gender differences and their statistical significance was taken into account (by means of chi-square).

Table 1. Characteristics of the study sample considering the particular primary school.

\begin{tabular}{ll}
\hline Name of the school & Number of pupils \\
\hline ZŠ s MŠ PIONIERSKA 2, BREZNO & 414 pupils \\
ZŠ s MŠ KAROLA RAPOŠA, PIONIERSKA 4, BREZNO & 293 pupils \\
ZŠ s MŠ MPČL 35, BREZNO & 114 pupils \\
\hline Total & 821 pupils \\
\hline
\end{tabular}

\section{RESULTS}

The first question of our questionnaire was related to the children's evaluation of their physical activities since, as stated by Frömel \& Bauman (2006), a physical activity has several functions in people's lives, e.g. restorative and compensatory functions, it provides a space for self-realization and aesthetic experience from the performance as well as feelings of satisfaction. It also increases and strengthens physical fitness and helps pupils make new friends and social contacts. In addition, physical activities develop moral qualities and rational cognitive process.

When evaluating the answers, we discovered that the pupils evaluate their physical activities positively, i.e. they spend a sufficient amount of time doing them. The answers provided by both boys and girls were similar and statistically non-significant (Table 2). 
Table 2. Pupils' positive attitude to physical activities.

\begin{tabular}{llll}
\hline & Yes & No & Undecided \\
\hline Girls & $77.48 \%$ & $10.81 \%$ & $11.71 \%$ \\
Boys & $81.06 \%$ & $6.82 \%$ & $12.12 \%$ \\
\hline
\end{tabular}

Subsequently, we were interested in how much time the pupils spend doing physical activities during weekdays and weekends. The fact that the majority of pupils (both boys and girls) are physically active for more than two hours a day, not only during weekends but also on weekdays (more than $44 \%$ of the girls and more than $51 \%$ of the boys), is very positive. More than $1 / 3$ of the girls spend one to two hours a day (during both weekdays and weekends) doing physical activities. We found out that $18 \%$ of the girls devote less than an hour (during both weekends and weekdays) to physical activities. When evaluating this question, we were surprised by the fact that the boys are physically less active during weekends since up to $24 \%$ of them spend less than an hour a day doing physical activities and $23 \%$ of them devote only one to two hours a day to physical activities. This was also reflected in the determination of statistically significant differences between boys and girls at the $p<0.01$ level of statistical significance.

According to that the given group of pupils should be encouraged to perform an adequate physical activity with specific aims since, according to Kucera \& Dylevsky (1999), physical activity has an effect on development and development affects the physical activity. This dynamic interrelationship clearly defines the significance of physical stimulation for pubescent age groups.

The most popular physical activities with the pupils include playful activities in the form of physical and sports games. As shown in Table 3,60.61\% of the boys find these activities their most favourite which may be caused by the fact that 2 out of 3 schools examined have sports classes specialized in football and ice hockey. Both boys and girls also like swimming as well as hiking. More than $17 \%$ of the boys and $27 \%$ of the girls chose the option "other (please specify)". As their favourite activities the boys listed cycling, inline skating and ice hockey and according to their answers, the girls prefer activities associated with music, e.g. Zumba and fitness. Considering the gender differences, the answers provided by the pupils were statistically significant at the level $p<0.01$ (Table 3 ).

Table 3. Physical activities carried out by the pupils.

\begin{tabular}{|c|c|c|c|c|}
\hline & Physical and sports games & Hiking & Swimming & Other \\
\hline Girls & $44.14 \%$ & $9.01 \%$ & $18.92 \%$ & $27.93 \%$ \\
\hline Boys & $60.61 \%$ & $12.88 \%$ & $9.09 \%$ & $17.42 \%$ \\
\hline
\end{tabular}

By evaluating the seventh question of the questionnaire, we ascertained that sports and physical education belongs to the most favourite subjects of the majority of the respondents On the other hand, up to $22 \%$ of the pupils (both boys and girls) do not include sports and physical education in the list of their favourite subjects. This finding explains the low percentage determined when evaluating the attractiveness of physical activities as such (Table 4). 
Table 4. Attractiveness of sports and physical education classes.

\begin{tabular}{llll}
\hline & yes & No & undecided \\
\hline Girls & $65.77 \%$ & $21.62 \%$ & $12.61 \%$ \\
Boys & $70.45 \%$ & $22.73 \%$ & $6.82 \%$ \\
\hline
\end{tabular}

The next question aimed at the determination of the most popular physical activities carried out at sports and physical education classes (Table 5).

Table 5. Popularity of physical activities carried out at sports and physical education classes.

\begin{tabular}{llllll}
\hline & Physical and sports games & Gymnastics & Athletics & Hiking & Other \\
\hline Girls & $68.47 \%$ & $12.61 \%$ & $9.01 \%$ & $8.11 \%$ & $1.80 \%$ \\
Boys & $75.00 \%$ & $7.589 \%$ & $5.30 \%$ & $6.82 \%$ & $5.3 \%$ \\
\hline
\end{tabular}

We ascertained that up to $68.47 \%$ of the girls and $75 \%$ of the boys find physical and sports games their most favourite activities. Since one of the schools is specialized in athletics, we were surprised by its low popularity percentage. Regarding the gender differences, we detected the $p<0.05$ level of statistical significance.

Results of the previous question were proven by the next one in which we asked the respondents about their attitude towards playful activities performed at sports and physical education classes. We discovered that playful activities are still very popular with most of the pupils $-78.38 \%$ of the girls and $78.38 \%$ of the boys chose "yes". Considering the gender differences, other answers to this question were very similar $12.61 \%$ of the girls and $13.64 \%$ of the boys answered "no". The rest of the pupils chose the option "undecided". The results show that the pupils (both boys and girls) enjoy sports games more than physical games (Table 6).

Table 6. Playful activities in the form of physical games or sports games.

\begin{tabular}{llll}
\hline & In the form of physical games & In the form of sports games & Undecided \\
\hline Girls & $36.94 \%$ & $59.91 \%$ & $3.15 \%$ \\
Boys & $31.44 \%$ & $65.91 \%$ & $2.65 \%$ \\
\hline
\end{tabular}

We assumed that in the case of the boys the reason is that the most of them attend specialized sports classes. Considering the gender differences, however, no statistically significant differences were observed. Subsequently, we were interested in the reason why pupils like physical games (Table 7). 
Table 7. Reasons for the popularity of physical games with pupils.

\begin{tabular}{llllll}
\hline & $\begin{array}{l}\text { Physical } \\
\text { activity }\end{array}$ & $\begin{array}{l}\text { New } \\
\text { experiences }\end{array}$ & $\begin{array}{l}\text { Playing in } \\
\text { a group }\end{array}$ & $\begin{array}{l}\text { Opportunity to Opportunity to } \\
\text { show one's skills }\end{array}$ & $\begin{array}{l}\text { tompete } \\
\text { compen }\end{array}$ \\
\hline Girls & $35.14 \%$ & $11.71 \%$ & $23.42 \%$ & $12.61 \%$ & $17.12 \%$ \\
Boys & $41.67 \%$ & $12.12 \%$ & $18.94 \%$ & $15.15 \%$ & $12.12 \%$ \\
\hline
\end{tabular}

The pupils (both boys and girls) like physical games most of all because they are related to physical activity. The second most common reason for the popularity of physical games with the boys and girls was the fact that they are played in groups. The third very common reason provided by the girls was the opportunity to compete $-17.12 \%$ of the answers. These activities enable them to experience exciting and joyful moments, the thrill of competition and rivalry as well as the blissful feelings of victory. We did not observe any statistically significant gender differences.

The pupils from our study sample also state that physical games are most often played in a gym $(63.06 \%$ of answers provided by the girls and $65.91 \%$ of answers provided by the boys). On the other hand, playful activities are far less commonly carried out in the nature during winter (since only $0.9 \%$ of the girls and $2.65 \%$ of the boys chose this option). The results also show that the pupils play physical games at sports and physical education classes at least once a week as indicated by the answers provided by $36.94 \%$ of the girls and $33.71 \%$ of the boys (Table 8 ).

Table 8. Frequency of physical games implementedin the course of sports and physical education classes.

\begin{tabular}{lllll}
\hline & at each PE class & at least once a week & at least once every 2 weeks & at least once a month \\
\hline Girls & $19.82 \%$ & $36.94 \%$ & $27.03 \%$ & $16.22 \%$ \\
Boys & $18.18 \%$ & $33.71 \%$ & $34.47 \%$ & $13.64 \%$ \\
\hline
\end{tabular}

When evaluating the frequency of physical games implemented in the course of sports and physical education classes, we discovered that the answers provided by both boys and girls were identical (almost $20 \%$ ). Considering the gender differences, however, no statistically significant differences were observed. Our findings are positive since Jan Amos Comenius also used games in educational process as a motivating factor to help understand and manage everyday tasks and assignments. He considered playing games to be a method of learning that is not perceived by children as a boring activity. In this sense, game represents one of the most important methods in educational process (Matuskova, 2006).

As can be concluded from the results, physical games are most often played in the main part of the class. The conclusion was indicated by the answers of both boys and girls. However, we determined the statistically significant gender differences at the $p<0.05$ level. Paradoxically, the pupils (both boys and girls) state that physical games are least commonly played in the introductory part of the class (Table 9). 
Table 9. Frequency of performance of physical games in particular parts of sports and physical education classes.

\begin{tabular}{llll}
\hline & introductory part & main part & final part \\
\hline Girls & $14.41 \%$ & $68.47 \%$ & $17.12 \%$ \\
Boys & $11.74 \%$ & $61.36 \%$ & $26.89 \%$ \\
\hline
\end{tabular}

Furthermore, we tried to ascertain what kinds of equipment are most commonly used at sports and physical education classes when playing physical games. The majority of respondents $(44.7 \%$ of the boys and $54.05 \%$ of the girls) state that they usually play games with various kinds of equipment, such as balls, skipping ropes, etc. This fact is undoubtedly related to actual material conditions and sports games carried out at sports and physical education classes. When evaluating this question regarding the gender differences, we observed the $p<0.05$ level of statistical significance.

The subsequent question aimed at pupils' interest in more frequent implementation of physical games in the course of sports and physical education classes. The answers to this question were unambiguous and almost identical with both boys and girls. The option "yes" was chosen by $87.39 \%$ of the girls and $88.64 \%$ of the boys. The selection of team members matters to the majority of the pupils $(63.64 \%$ of the boys and $72.97 \%$ of the girls). Most of the boys $(63.64 \%)$ and girls $(72.97 \%)$ hold the opinion that games are more fun when more participants are involved. However, $28.79 \%$ of the boys do not agree with this statement (the option "no" was selected only by $13.51 \%$ of the girls). The differences between answers provided by the boys and girls were statistically significant at the $p<0.01$ level.

The pupils believe that when playing physical games they can make contact with their classmates in a faster way. $63.64 \%$ of the boys and $54.95 \%$ of the girls are convinced of this fact. Considering this question, no statistically significant differences between the boys and girls were observed. This fact has to be taken into account mainly during puberty.

Finally, we were interested in the pupils' attitude towards the importance of physical activity in their lives. $89.19 \%$ of the girls and $87.12 \%$ of the boys are aware of the importance of physical games. We perceive this fact as positive since pupils at the 2 nd stage of primary schools (Novotna \& Adamcak, 2002) should already be familiar with the importance of regular physical activity for health. It is every teacher's duty to inform pupils about the wide range of physical activities with positive health effects.

\section{DISCUSSION}

The fact that the majority of pupils are physically active for more than two hours a day, not only during weekends but also on weekdays (more than $44 \%$ of the girls and more than $51 \%$ of the boys), is very positive. This is also a positive finding since, according to Cavill et al., (2001), children should devote at least an hour a day to physical activities. Simonek (2006) suggests that children aged $10-17$ should spend 3 hours a day (20 hours a week) doing physical activities.

It was found that up to $68.47 \%$ of the girls and $75 \%$ of the boys find physical and sports games their most favourite activities, which is in accordance with the findings of Kozanakova (2011). Regarding the gender differences, we detected the $p<0.05$ level of statistical significance. 
The majority of respondents ( $44.7 \%$ of the boys and $54.05 \%$ of the girls) state that they usually play games with various kinds of equipment, such as balls, skipping ropes, etc. According to Novotna et al., (2007) the use of various aids motivates pupils to perform activities which they would not be interested in without using them.

The pupils (both boys and girls) like physical games most of all because they are related to physical activity. The second most common reason for the popularity of physical games with the boys and girls was the fact that they are played in groups. The third very common reason provided by the girls was the opportunity to compete $-17.12 \%$ of the answers. According to Argaj (2004), games and playful activities help children satisfy their need for company, get them out of loneliness and allow them to communicate with others. In games, children find new friends as well as opponents with whom they can co-operate or compete.

The pupils believe that when playing physical games they can make contact with their classmates in a faster way. $63.64 \%$ of the boys and $54.95 \%$ of the girls are convinced of this fact. According to Vagnerova (2005), in this period of life, people of the same age (peer group) are more and more important for the pubescent, because they provide them with emotional and social support, friendships and first love. There is a hierarchy among the pubescent and each group has its leader.

The pupils from our study sample also state that physical games are most often played in a gym $(63.06 \%$ of answers provided by the girls and $65.91 \%$ of answers provided by the boys). According to Novotna et al., (2009), pupils spend most of their time doing unorganized outdoor games - 93.1 minutes per child. On average, children play games for 86.1 minutes on weekdays and 110.4 minutes during weekends.

\section{CONCLUSION}

Based on the results of our research, we present the following findings:

Regular physical activity is carried out by $77.48 \%$ of the girls and $81.06 \%$ of the boys.

For $68.47 \%$ of the girls as well as $75 \%$ of the boys, physical and sports games are the most popular activities at sports and physical education classes.

Sports and physical education belongs to the favourite subjects of the majority of the girls $(65.77 \%)$ and boys $(70.45 \%)$.

The pupils like physical games mostly because of the opportunity to be physically active $(41.67 \%$ of the boys and $35.14 \%$ of the girls).

$87.39 \%$ of the girls and $88.64 \%$ of the boys would like to play games at their sports and physical education classes more often.

The research showed that physical games still represent the key factor not just in motivating pupils of primary schools to perform regular physical activities, but also in increasing the popularity of sports and physical education classes.

We are aware that it is important for every sports and physical education teacher to identify with it and approach physical games and education in the following manner: "Teachers should not stand like 
mileposts, which show you where to go although they do not move themselves" as stated by Jan Amos Comenius.

\section{REFERENCES}

1. Adamcak, S. (2009). The opinions of pupils on integration of frisbee into teaching process. Acta Universitatis Matthiae Belii Physical education and Sport, 1(1), pp.7-11.

2. Argaj, G. (1999). Nové prístupy k vyučovaniu pohybových hier. Športové hry, 4(1), pp.24-33.

3. Argaj, G. (2004). Pohybové hry a rozvoj tvorivosti hráčov. Športové hry, 9(1), pp.14-20.

4. Argaj, G. (2011). Nové možnosti využitia pohybových hier v telesnej a športovej výchove po kurikulárnej transformácii na Slovensku. Tel. Vých. Šport, 16(4), pp.13-14.

5. Baranek, D. \& Hrnciar, T. (2009) The position of floorball as a sports game at selected comprehensive schools in the region of Banská Bystrica. Acta Universitatis Matthiae Belii Physical education and Sport, 1(1), pp.18-25.

6. Cavill, N., Biddle, S. \& Sallis, J.F. (2001). Health enhancing physical activity for young people. Pediatr Excerc Sci, 13, pp.12-25.

7. Fromel, K. \& Bauman, A. (2006). Intenzita a objem pohybové aktivity 15-69leté populace České republiky. Česká kinantropologie, 10(1), pp.13-27.

8. Kozanakova, A. (2011). Využitie pohybových hier v školskej telesnej výchove u dievčat 2.stupňa ZŠ. Exercitatio corpolis-motus-salus, 3(1), pp.132-142.

9. Kucera, M. \& Dylevsky, I. (1999). Sportovní medicina. Praha: Grada Publishing.

10. Matuskova, R. (2006). Hra ako jedna z vyučovacích metód. Naša škola, 1, pp.23-29.

11. Michal, J. (2010). Interest about physical activities at elementary schools. Acta Universitatis Matthiae Belii Physical education and Sport, 2(2), pp.77-83.

12. Novotna, N., Vladovicova, N. \& Adamcak, S. (2009). Programy v pohybovom režime žiakov mladšieho školského veku banskobystrického regiónu ako determinant ich zdravia. Banska Bystrica: FHV UMB.

13. Novotna, N. \& Adamcak, S. (2002). Názory učitel'ov na zaradenie strečingu do hodín telesnej výchovy. Tel. Vých. Šport, 12(2), pp.25-28.

14. Novotna, N., Blahutkova, M. \& Ottmarova, E. (2007). Hry s netradičným náčiním. Banska Bystrica: PF UMB.

15. Simonek, J. (2006). Športové záujmy a pohybová aktivita v dennom režime a ich vplyv na prevenciu drogových závislostí detí a mládeže. Nitra: PF UKF.

16. Vagnerova, M. (2005). Vývojová psychologie I.: dětství a dospívání. Praha: Karolinum. 